\title{
KEABSAHAN METODE ANALISIS KADAR PCMX (p-chloro $m$-xylenol) DALAM SABUN CAIR ANTISEPTIK
}

\author{
Nurlela \\ Program Studi Kimia FMIPA Universitas Nusa Bangsa Bogor \\ Jl. KH Soleh Iskandar KM 4 Cimanggu Tanah Sareal, Bogor 16166 \\ e-mail: nnurlela16@gmail.com
}

\author{
ABSTRACT \\ Validity of Analysis Method for PCMX (p-chloro m-xylenol) Concentration \\ in Antiseptic Liquid Soap
}

\begin{abstract}
PCMX (p-chloro m-xylenol) is an active substance functioning to kill bacteria (bactericide), generally added to the formula of soap, detergents, antiseptics, disinfectants and various other products. The purpose of this study was to verify the validity of PCMX concentration analysis method in antiseptic liquid soap using High PerformanceLiquid Chromatograph (HPLC)so that it was trustworthy and could be used as a routine analysis in the Quality Assurance Laboratory of Reckitt Benckiser Indonesia Company. Parameters of analysis method performance were selectivity, linearity, instrument precision, repeatability, intermediete precision, and accuracy. The mobile phase used was a mixture of methanol and $1 \% \mathrm{v} / \mathrm{v}$ glacial acetat acid in de-ionized water with the ratio of 55:45. The HPLC Agilent 1200 UV detector was given the following setting: Spherisorb 5 ODS 1 coloumn $(150 \times 4,6) \mathrm{mm}$, flow rate $2,0 \mathrm{ml} / \mathrm{min}$, injection volume $20 \mu \mathrm{L}$, detection $U V$ at $280 \mathrm{~nm}$, temperature $40^{\circ} \mathrm{C}$, and run time 20 minutes. The validation result in: selectivity test, analyte (PCMX) devider peak without disturbance from other components in the sample; linearity test: $r>0,9996$; instrument precision: RSD percentage values for standard solution 0,028 $\mathrm{mg} / \mathrm{L}$ and 0,036 $\mathrm{mg} / \mathrm{L}$ were $0,08 \%$ and $0,45 \%$ respectively; repeatability: RSD percentage value was 0,98\%; intermediate precision: the method didn't give any real difference in different analysis in adifferent execution period; and accuracy: recovery value was 108,98\%. Based on the result, it could be concluded that this method of analysis was trustworthy and could be used as a routine analysis at Reckitt Benckiser Indonesia Company.
\end{abstract}

Keywords: Validity of Analysis Method, PCMX (p-chloro m-xylenol), High Performance Liquid Chromatograph

\begin{abstract}
ABSTRAK
PCMX (p-chloro m-xylenol) merupakan zat aktif yang berfungsi mematikan bakteri (bakterisida), umumnya ditambahkan ke dalam formula sabun, detergen, antiseptik, desinfektan, dan berbagai produk lainnya. Penelitian ini bertujuan untuk membuktikan keabsahan metode analisis kadar PCMX dalam sabun cair antiseptik menggunakan Kromatografi Cair Kinerja Tinggi (KCKT) sehingga layak dan dapat dipercaya untuk analisis rutin di laboratorium Quality Assurance PT Reckitt Benckiser Indonesia. Parameter kinerja metode analisis mencakup selektivitas, linieritas, presisi, dan akurasi. Fase gerak yang digunakan adalah campuran antara metanol dan larutan asam asetat glasial $1 \% \mathrm{v} / \mathrm{v}$ dalam de-ionized water dengan perbandingan 55:45. Pengukuran dilakukan menggunakan KCKT Agilent 1200 UV detector dengan pengaturan sebagai berikut: kolom 150 x 4,6 mm Spherisorb 5 ODS 1, kecepatan alir 2,0 mL/min, volume injeksi $20 \mu \mathrm{L}$, panjang gelombang $280 \mathrm{~nm}$, temperatur $40^{\circ} \mathrm{C}$, dan waktu analisis 20 menit. Hasil pengujian diperoleh uji selektivitas berupa peak yang mampu memisahkan analit (PCMX) dalam sampel tanpa gangguan dari komponen lain dalam sampel. Uji linieritas menghasilkan $r>0,9996$. Presisi instrumen menghasilkan \% RSD untuk konsentrasi larutan standar $0,028 \mathrm{mg} / \mathrm{mL}$ dan $0,036 \mathrm{mg} / \mathrm{mL}$ berturut-turut adalah $0,08 \%$ dan $0,45 \%$. Keterulangan menghasilkan \% RSD sebesar $0,98 \%$. Presisi antara menunjukkan bahwa metode analisis tidak memberikan hasil yang bervariasi (berbeda nyata) jika dilakukan oleh analis yang berbeda pada waktu yang berbeda dan uji akurasi menghasilkan \%recovery sebesar 108,98\%. Berdasarkan hasil kinerja metode analisis kadar PCMX tersebutdapat disimpulkan bahwa metode analisis ini valid, sehingga layak untuk digunakan di laboratorium Quality Assurance PT Reckitt Benckiser Indonesia.
\end{abstract}

Kata Kunci: Keabsahan Metode, PCMX (p-chloro m-xylenol), Kromatografi Cair Kinerja Tinggi 


\section{PENDAHULUAN}

Penggunaan sabun antiseptik merupakan salah satu bentuk perlindungan terhadap kesehatan. Sabun antiseptik berfungsi untuk membunuh bakteri dan menghambat pertumbuhan jamur. Dalam kegiatan sehari-hari, manusia tidak dapat terlepas dari kontaminasi bakteri, jamur, bahkan virus. Untuk mencegah penyakit yang ditimbulkan oleh kontaminan tersebut, maka sangat dianjurkan untuk menggunakan sabun antiseptik. Untuk menjamin bahwa masyarakat akan menerima produk yang bermutu dan aman, maka pemerintah mewajibkan industri yang bergerak di bidang kosmetika untuk memenuhi persyaratan Cara Pembuatan Kosemetika yang Baik (CPKB). Kosmetika yaitu suatu bahan atau sediaan yang dimaksud untuk digunakan pada berbagai bagian dari badan atau gigi dan selaput lendir di rongga mulut dengan maksud untuk membersihkannya, membuat wangi atau melindungi supaya tetap dalam keadaan baik, mengubah penampilan, atau menghilangkan bau badan (BPOM, 2003). Sedangkan CPKB merupakan pedoman yang bertujuan untuk memastikan agar kosmetika yang diproduksi bermutu dan aman digunakan oleh masyarakat.

Dalam rangka memenuhi persyaratan tersebut maka metode pengujian terhadap zat aktif yang terkandung dalam produk harus divalidasi terlebih dahulu untuk memperoleh data kuantisasi yang valid atau absah. Parameter validasi yang diuji adalah selektivitas, linieritas, presisi instrumen, keterulangan, presisi antara, dan akurasi.

Metode penetapan kadar PCMX dalam sabun cair antiseptik menggunakan KCKT mengacu pada Test Method 65264 - TM EU (Reckitt Benckiser plc). Penetapan ini sebelum-nya dilakukan dengan menggunakan Test Method 65029 - TM EU (Reckitt Benckiser plc). Selain itu, validasi ini dilakukan dengan menggunakan KCKT baru yang akan digunakan di Laboratorium Quality Assurance PT Reckitt Benckiser
Indonesia. Oleh karena itu, untuk memastikan bahwa metode analisis tersebut dapat memberikan data kuantitasi PCMX yang valid dan dapat digunakan untuk pengujian secara rutin di laboratorium QA PT Reckitt Benckiser Indonesia, maka dilakukan validasi metode analisis.

\section{BAHAN DAN METODE}

Penelitian ini dilakukan di laboratorium Quality Assurance (QA) PT Reckitt Benckiser Indonesia, Jl. Raya Narogong Km 15 Desa Limusnunggal Pangkalan VIII Kec. Cileungsi, Kab. Bogor. Penelitian ini dilakukan pada bulan Januari-Maret 2010.

\begin{abstract}
Alat
Alat-alat yang digunakan meliputi KCKT Agilent 1200 with UV detector, neraca analitik mettler toledo AG 285, sonicator Power Sonic 405, vial, kertas saring whatman No.40 (ashless, circles $125 \mathrm{~mm} \varnothing$ ), pipet volume Iwaki Pyrex grade B $10 \mathrm{~mL} \pm 0,03 \mathrm{~mL}$ ex $20{ }^{\circ} \mathrm{C}$, labu ukur Iwaki Pyrex grade A $100 \mathrm{~mL} \pm$ $0,01 \mathrm{~mL}$ in $20^{\circ} \mathrm{C}$, pipet tetes.
\end{abstract}

\section{Bahan}

Bahan-bahan yang digunakan adalah PCMX Lot No. 090109001 dengan kemurnian 102,1\%, metanol (Merck, HPLC grade), asam asetat glasial (Merck, analytical grade), metanol (Merck, analytical grade), deionized water, plasebo.

\section{Rancangan Penelitian}

Metode penetapan kadar PCMX dalam sabun cair antiseptik menggunakan KCKT mengacu pada Test Method 65264-TM EU (Reckitt Benckiser plc). Sebelumnya mengacu pada Test Method 65029-TM EU (Reckitt Benckiser plc). Selain itu kinerja metode ini dilakukan dengan menggunakan KCKT baru yang akan digunakan di PT Reckitt Benckiser Indonesia. 
Metode Kerja

Kondisi KCKT

Kolom

: $(150 \times 4,6) \mathrm{mm}$ Spherisorb 5 ODS 1

Kecepatan alir : $2,0 \mathrm{~mL} / \mathrm{menit}$

Volume sampel $: 20 \mu \mathrm{L}$

Panjang gelombang UV : $280 \mathrm{~nm}$

Temperatur $\quad: 40{ }^{\circ} \mathrm{C}$

Waktu analisis $\quad: 20$ menit

\section{Fase Gerak}

Fase gerak yang digunakan adalah campuran antara metanol dan larutan asam asetat glasial $1 \% \mathrm{v} / \mathrm{v}$ dalam deionized water dengan perbandingan $55: 45$.

\section{Pembuatan Larutan Standar}

Ditimbang teliti 0,0490 g PCMX standar dan dimasukkan ke dalam labu ukur $100 \mathrm{~mL}$. PCMX dilarutkan dan ditera dengan metanol di dalam labu ukur $100 \mathrm{~mL}$ (konsentrasi larutan standar $1=0,05 \mathrm{mg} / \mathrm{L}$ ). Larutan disaring dengan kertas saring whatman no.40.

\section{Preparasi Larutan Sampel}

Ditimbang teliti $1,500 \mathrm{~g}$ contoh, dilarutkan ke dalam labu ukur $100 \mathrm{~mL}$, ditambahkan $\pm 60 \mathrm{~mL}$ metanol kemudian dihomogenisasi menggunakan $u l$ trasonic dengan kecepatan $175 \mathrm{rpm}$ selama 15 menit. Setelah itu, larutan ditera dengan metanol. Larutan disaring dengan kertas saring whatman No.40.

\section{Preparasi Larutan Plasebo}

Plasebo ditimbang teliti sebanyak $1,500 \mathrm{~g}$, dilarutkan ke dalam labu ukur $100 \mathrm{~mL}$, ditambahkan $\pm 60 \mathrm{~mL}$ metanol kemudian dihomogenisasi menggunakan ultrasonic dengan kecepatan $175 \mathrm{rpm}$ selama 15 menit. Setelah itu, larutan ditera dengan metanol. Larutan disaring dengan kertas saring whatman No.40.

\section{Uji Kesesuaian Sistem}

Uji kesesuain sistem dapat dilakukan dengan cara diinjeksikan larutan standar sebanyak lima kali ke dalam KCKT. Dihitung daya pisah, faktor ikutan, dan lempeng teoritis.

\section{Uji Selektivitas}

Larutan standar, larutan plasebo, dan larutan sampel masing-masing dimasukkan ke dalam vial kemudian diinjeksikan masing-masing sebanyak $3 \mathrm{x}$ ke dalam KCKT. Peak kromatogram dari masing-masing larutan disbandingkan

\section{Uji Linieritas}

Larutan standar induk 1 dibuat dengan cara ditimbang 0,049 g PCMX standar ke labu ukur $100 \mathrm{~mL}$ kemudian dilarutkan dengan metanol $50 \mathrm{~mL}$ dan dihomogenisasi menggunakan ultrasonic. Larutan dihimpitkan sampai tanda tera dengan metanol. Dibuat larutan standar 2 dengan cara ditimbang 0,0979 g PCMX standar ke labu ukur $100 \mathrm{~mL}$ kemudian dilarutkan dengan metanol 50 $\mathrm{mL}$ dan dihomogenisasi menggunakan ultrasonic. Larutan dihimpitkan sampai tanda tera dengan metanol.

Dipipet $1,2 \mathrm{~mL} ; 2,7 \mathrm{~mL} ; 5,7 \mathrm{~mL}$ larutan standar induk 1 ke dalam masing-masing labu takar $100 \mathrm{~mL}$. Dipipet $3,6 \mathrm{~mL} ; 4,3 \mathrm{~mL} ; 5,8 \mathrm{~mL} ; 6,6 \mathrm{~mL}$ larutan standar 2 ke dalam masingmasing labu takar $100 \mathrm{~mL}$, kemudian larutan dihimpitkan dengan metanol. Larutan disaring dengan kertas saring whatman No.40 dan dimasukkan ke dalam vial KCKT kemudian ditutup. Larutan diinjeksikan ke dalam sistem KCKT sebanyak $3 \mathrm{x}$ pengulangan. Dihitung slope, intersep, dan koefisien korelasi (r) dari regresi linier yang didapat. 


\section{Presisi}

\section{Presisi Instrumen}

Larutan standar uji linieritas pada konsentrasi $0,028 \mathrm{mg} / \mathrm{L}$ dan $0,036 \mathrm{mg} / \mathrm{L}$ diinjeksikan sebanyak 10 kali ke dalam KCKT. Dihitung simpangan baku relatifnya (\% RSD).

\section{Keterulangan (repeatability)}

PCMX (kemurnian 102,1\%) ditimbang sebanyak $0,0102 \mathrm{~g}$ ke dalam labu ukur $100 \mathrm{~mL}$ dan ditambahkan dengan plasebo sebanyak 5,9510 g kemudian dilarutkan dengan $50 \mathrm{~mL}$ metanol dan dihomogenisasi menggunakan ultrasonic. Larutan dihimpitkan menggunakan metanol sampai tanda tera (konsentrasi larutan $=0,175 \% \mathrm{~b} / \mathrm{b}$ ). Larutan disaring dengan kertas saring whatman dan dimasukkan ke dalam vial KCKT. Larutan diinjeksikan dan dilakukan replikasi sebanyak 6 kali. Dihitung simpangan baku relatifnya (\% RSD).

\section{Presisi Antara}

Presisi antara dilakukan oleh 2 analis yang berbeda dan waktu yang berbeda. Pengujian dilakukan dengan cara ditimbang 0,0102 g PCMX (kemurnian 102,1\%) ke dalam labu ukur $100 \mathrm{~mL}$ dan ditambahkan dengan plasebo sebanyak 5,9510 g kemudian dilarutkan dengan $50 \mathrm{~mL}$ metanol dan dihomogenisasi menggunakan ultrasonic. Larutan dihimpitkan menggunakan metanol sampai tanda tera (konsentrasi larutan $=0,175 \% \mathrm{~b} / \mathrm{b}$ ). Larutan disaring dengan kertas saring whatman dan dimasukkan ke dalam vial KCKT. Larutan diinjeksikan dan dilakukan replikasi sebanyak 6 kali. Dihitung \% RSD, hasil yang diperoleh oleh analis pertama dibandingkan dengan analis kedua menggunakan uji $\mathrm{F}$ dan uji t.

\begin{abstract}
Akurasi
PCMX Ditimbang 0,0102 g (kemurnian 102\%) ke dalam labu ukur 100 $\mathrm{mL}$ dan ditambahkan 5,9510 g plasebo. Kemudian dilarutkan dengan $50 \mathrm{~mL}$ metanol dan dihomogenisasi menggunakan ultrasonic. Larutan dihimpitkan menggunakan metanol sampai tanda tera. Larutan disaring dengan kertas saring whatman no.40 dan dimasukkan ke dalam vial KCKT. Larutan diinjeksikan dan dilakukan replikasi sebanyak 6 kali. Dihitung persen perolehan kembali (\%recovery).
\end{abstract}

\section{Kriteria Penerimaan}

Tabel 1. Kriteria Penerimaan KinerjaMetode Analisis Penetapan Kadar PCMX dalam Sabun Cair Antiseptik secara KCKT.

\begin{tabular}{cc}
\hline Parameter & Kriteria Penerimaan \\
\hline Faktor Ikutan (Tailing Factor) & $<2,0$ \\
Lempeng Teoritis (Theoretical Plate) & $>1000$ \\
Linieritas & $\mathrm{r}>0,99$ \\
Presisi & RSD $<10 \%$ \\
Akurasi & \% Recovery $=80-120 \%$ \\
\hline
\end{tabular}

Sumber: (APVMA, 2003) 


\section{HASIL DAN PEMBAHASAN}

\section{Uji Kesesuaian Sistem}

Uji kesesuaian sistem merupakan bagian yang integral dari banyak prosedur analitik. Pengujian ini berdasarkan pada konsep bahwa peralatan uji, elektronika, pengerjaan analisis, dan pengujian sampel merupakan suatu sistem integral yang dapat dievaluasi. Berikut hasil dari uji kesesuaian sistem:

\section{Faktor ikutan (Tailing Factor)}

Faktor ikutan menunjukkan kesimetrisan suatu peak. Peak yang sempurna adalah peak yang simetris. Bila ditarik garis lurus yang melalui peak sampai ke garis alas, maka sisi kanan akan sama dengan sisi kiri. Semakin simetris peak tersebut semakin memudahkan pada saat integrasi dan biasanya intensitas tanggap detektornya lebih tinggi.

Tabel 2. Data Hasil Uji Kesesuaian Sistem

\begin{tabular}{ccc}
\hline $\begin{array}{c}\text { Larutan } \\
\text { Standar }\end{array}$ & $\begin{array}{c}\text { Faktor } \\
\text { Ikutan }\end{array}$ & $\begin{array}{c}\text { Lempeng } \\
\text { Teoritis }\end{array}$ \\
\hline 1 & 0,961 & 4129 \\
2 & 0,962 & 4128 \\
3 & 0,959 & 4151 \\
4 & 0,958 & 4162 \\
5 & 0,964 & 4180 \\
Rata-rata & 0,9608 & 4150 \\
\hline
\end{tabular}

Dari hasil pengukuran KCKT pada Tabel 2 diperoleh nilai rata-rata faktor ikutan 0,9608. Nilai tersebut memenuhi persyaratan yaitu $<2,0$. Hal ini menunjukkan bahwa peak yang dihasilkan KCKT tersebut simetris. Peak dapat dilihat pada Lampiran.

\section{Lempeng Teoritis}

Lempeng teoritis adalah banyaknya distribusi kesetimbangan dinamis yang terjadi di dalam kolom atau disebut juga dengan keefisienan kolom. Semakin banyak lempeng teoritis yang terjadi, peak yang dihasilkan semakin runcing. Dengan demikian kuantitasnya lebih baik karena integrator bisa lebih tepat menentukan peak front dan peak end.

Dari hasil pengukuran KCKT (Tabel 2) diperoleh nilai 4150. Nilai tersebut memenuhi persyaratan yaitu > 1000. Hal ini menunjukkan bahwa kolom yang digunakan pada KCKT tersebut efisien dalam melakukan pemisahan. Peak dapat dilihat pada Lampiran.

\section{Kinerja Metode Analisis Selektivitas}

Selektivitas atau spesifisitas suatu metode adalah kemampuan suatu metode menetapkan suatu analit dalam suatu campuran tanpa gangguan dari komponen lain dalam campuran tersebut. Selektivitas juga dapat di-definisikan sebagai kemampuan suatu metode menetapkan masing-masing komponen yang terdapat dalam campuran suatu bahan.

Dari pengukuran larutan standar diperoleh peak yang dapat menetapkan analit (PCMX) dengan baik. Dari pengukuran larutan sampel diperoleh peak yang dapat menetapkan analit dengan baik tanpa ada gangguan dari komponen lain dalam campuran. Sedangkan dari pengukuran larutan plasebo diperoleh peak berbagai komponen dalam campuran tanpa adanya peak analit.

Hasil dari uji selektivitas menunjukkan bahwa metode analisis ini mampu mengukur PCMX dalam tanpa gangguan dari komponen lain dalam campuran.

\section{Linieritas}

Linieritas dapat didefinisikan sebagai kemapuan suatu metode analisis untuk memperoleh hasil uji yang sebanding dengan konsentrasi analit dalam sampel dalam rentang validasi. Rentang validasi yaitu rentang yang mencakup konsentrasi yang lebih tinggi dan lebih rendah dari konsentrasi analit 
dalam sampel yang dianalisis, rentang tersebut harus dapat digunakan untuk menunjukkan tingkat presisi, akurasi, dan linieritas suatu metode. Linieritas biasanya dinyatakan dalam koefisien korelasi (r). nilai $\mathrm{r}$ berkisar antara $-1,0$ sampai $+1,0$. Linieritas yang baik atau adanya korelasi yang erat ditunjukkan dengan nilai koefisien korelasi (r) yang mendekati satu (positif maupun negatif). Nilai nol menunjukkan tidak adanya korelasi.

Uji linieritas dilakukan dengan membuat larutan dari bahan baku PCMX dengan konsentrasi 50-150\%. Hasil analisis dibuat kurva hubungan antara konsentrasi larutan standar (konsentrasi teori) dengan luas peak (konsentrasi terukur) kemudian dibuat garis regresi.

Data hasil uji linieritas pada Tabel 3 dibuat kurva hubungan antara konsentrasi larutan standar dengan luas peak rata-rata. Kemudian dihitung nilai koefisien korelasi.

Kurva linieritas pada Gambar 1 diperoleh nilai koefisien korelasi 0,9996 . Nilai ini memenuhi persyaratan yaitu $r>0,990$. Hal ini menunjukkan bahwa pada konsentrasi kerja 50-150\% masih memberikan korelasi yang berbanding lurus antara respon deteksi alat terhadap nilai kadar teori dari analit yang diukur.

Tabel 3. Data Hasil Uji Linieritas

\begin{tabular}{ccccc}
\hline $\begin{array}{c}\text { Konsentrasi } \\
(\mathrm{mg} / \mathrm{mL}) \\
(50 \%-150 \%)\end{array}$ & $\begin{array}{c}\text { Luas } \\
\text { Peak } 1\end{array}$ & $\begin{array}{c}\text { Luas } \\
\text { Peak } 2\end{array}$ & $\begin{array}{c}\text { Luas } \\
\text { Peak 3 }\end{array}$ & $\begin{array}{c}\text { Luas Peak } \\
\text { Rata-rata }\end{array}$ \\
\hline 0,006 & 33,6920 & 34,0017 & 33,6165 & 33,7701 \\
0,014 & 73,1881 & 72,8858 & 73,1056 & 73,0598 \\
0,028 & 153,2862 & 153,1616 & 153,4571 & 153,3016 \\
0,036 & 189,2251 & 189,6632 & 189,7874 & 189,5586 \\
0,043 & 227,1220 & 227,1365 & 228,2805 & 227,5130 \\
0,058 & 306,7277 & 307,4451 & 307,0077 & 307,0602 \\
0,066 & 352,4424 & 352,7774 & 352,5024 & 352,5741 \\
\hline
\end{tabular}

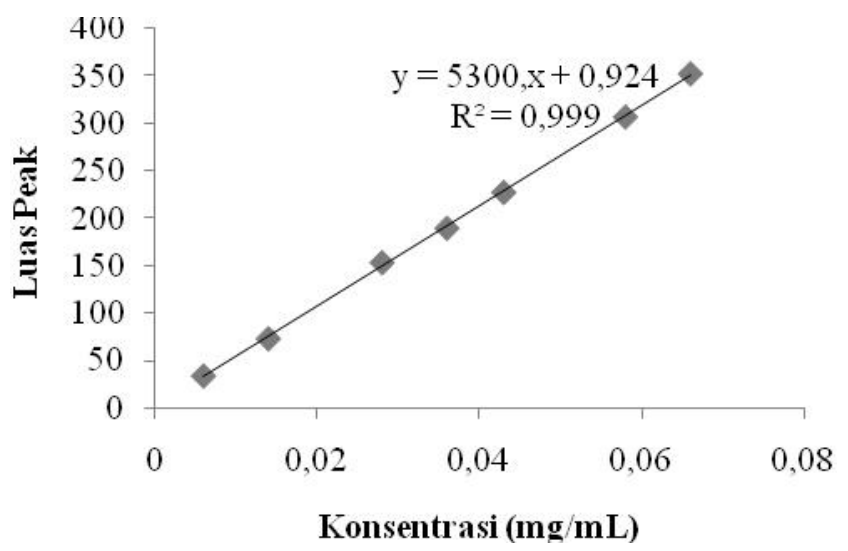

Gambar 1. Kurva Hasil Uji Linieritas 


\section{Presisi}

Presisi didefinisikan sebagai kedekatan antara hasil pengujian individu dalam serangkaian pengukuran terhadap suatu sampel yang homogen dengan melakukan pengambilan sampel menurut prosedur yang telah ditentukan. Presisi dinyatakan dengan persen Relative Standard Deviation (\% RSD) dari data yang diperoleh.

Tabel 4. Kriteria Penerimaan Presisi

\begin{tabular}{cc}
\hline $\begin{array}{c}\text { Konsentrasi Analit } \\
(\% \mathrm{~b} / \mathrm{v})\end{array}$ & $\begin{array}{c}\text { Presisi } \\
(\% \mathrm{RSD})\end{array}$ \\
\hline$>10 \%$ & $<2 \%$ \\
$1,0-10,0 \%$ & $<5 \%$ \\
$0,1-1,0 \%$ & $<10 \%$ \\
$<0,1 \%$ & $<20 \%$ \\
\hline Presisi umumnya & meliputi
\end{tabular}
pengujian repeatability, intermediate precision, dan reproducibility. Dapat juga dilakukan pengujian presisi instrumen (alat uji yang digunakan untuk mengukur analit dalam sampel). Presisi dinyatakan dalam \% RSD.

\section{Presisi Instrumen}

Pengujian presisi instrumen bertujuan untuk mengetahui kemampuan KCKT menghasilkan data yang berdekatan dalam melakukan pengukuran secara berulang terhadap sampel yang homogen. Pengujian presisi instrumen dilakukan dengan menginjeksikan larutan standar pada konsentrasi tertentu sebanyak 10 kali, kemudian dihitung \% RSD.

Pengolahan data pada Tabel 5 diperoleh \% RSD untuk konsentrasi $0,028 \mathrm{mg} / \mathrm{mL}$ dan $0,036 \mathrm{mg} / \mathrm{mL}$ berturut-turut adalah $0,08 \%$ dan $0,45 \%$. Nilai tersebut memenuhi persyaratan yaitu $<10 \%$. Hal ini menunjukkan bahwa instrumen yang digunakan yaitu HPLC Agilent 1200 mampu menghasilkan keterulangan data pengukuran terhadap sampel homogen.

\section{Keterulangan (Repeatability)}

Keterulangan menyatakan presisi yang dilakukan pada kondisi yang telah ditentukan pada laboratorium yang sama, dalam interval waktu yang singkat, oleh analis yang sama, dengan menggunakan peralatan dan pereaksi yang sama. Keterulangan dilakukan dengan cara menguji suatu sampel dengan konsentrasi tertentu sebanyak enam kali penetapan (replikasi). Pelaksanaan uji keterulangan adalah untuk menggambarkan kesalahan acak dan ketidakseragaman hasil analisis yang dilakukan. Pengujian dilakukan pada konsentrasi analit $0,1-1,0 \%$.

Tabel 5. Data Hasil Uji Presisi Instrumen

\begin{tabular}{ccc}
\hline Injeksi ke- & \multicolumn{2}{c}{ Luas Peak } \\
\cline { 2 - 3 } & $\begin{array}{c}\text { Larutan Standar } \\
(0,028 \mathrm{mg} / \mathrm{mL})\end{array}$ & $\begin{array}{c}\text { Larutan Standar } \\
(0,036 \mathrm{mg} / \mathrm{mL})\end{array}$ \\
\hline 1 & 153,0560 & 188,4664 \\
2 & 152,9595 & 190,3283 \\
3 & 152,9376 & 190,2172 \\
4 & 153,0790 & 190,6996 \\
5 & 152,9909 & 190,8843 \\
6 & 152,9574 & 190,8911 \\
7 & 152,7778 & 190,8560 \\
8 & 153,1742 & 190,2201 \\
9 & 152,8349 & 190,1999 \\
10 & 153,1095 & 191,6853 \\
Rata-rata: & 152,9877 & 190,5448 \\
SD: & 0,1221 & 0,8632 \\
\% RSD: & $0,08 \%$ & $0,45 \%$ \\
\hline
\end{tabular}


Tabel 6. Data Hasil Uji Keterulangan

\begin{tabular}{cccccc}
\hline $\begin{array}{c}\text { Ulangan } \\
\text { ke- }\end{array}$ & & Luas Peak & $\begin{array}{c}\text { Luas Peak } \\
\text { Rata-rata }\end{array}$ & $\begin{array}{c}\text { Konsentrasi } \\
\text { Terukur }\end{array}$ \\
\hline 1 & 593,1733 & 593,4668 & 592,4034 & 593,0145 & 0,191 \\
2 & 583,9637 & 594,2949 & 594,1350 & 590,7978 & 0,190 \\
3 & 588,0665 & 592,7877 & 590,2080 & 590,3541 & 0,190 \\
4 & 579,7306 & 582,1574 & 583,3267 & 581,7382 & 0,187 \\
5 & 594,2650 & 593,7499 & 593,3348 & 593,7832 & 0,191 \\
6 & 578,8405 & 579,7560 & 587,1621 & 581,9195 & 0,187 \\
\hline Rata-rata: & & & 0,1893 & & \\
SD: & & & 0,0019 & & \\
\% RSD & & & $0,9834 \%$ & & \\
\hline
\end{tabular}

Dari hasil pengolahan data pada Tabel 6 diperoleh nilai \% RSD 0,98\%. Nilai ini telah memenuhi persyaratan yaitu $<10 \%$. Hal ini menunjukkan bahwa metode ini sesuai dengan kondisi laboratorium, pereaksi, dan alat yang digunakan.

\section{Presisi Antara (Intermediate Precision)}

Presisi antara menyatakan presisi yang dilakukan pada kondisi yang telah ditentukan pada laboratorium yang sama, pada hari yang berbeda, dan oleh analis yang berbeda. Pengolahan data dasil analisis dilakukan dengan metode statistik yaitu dengan uji $\mathrm{F}$ dan $\mathrm{t}$ hitung. Kriteria penerimaan uji $\mathrm{t}$ dinyatakan dengan nilai t hitung kurang dari $\mathrm{t}$ tabel, hal ini menunjukkan bahwa tidak terdapat perbedaan secara nyata antara dua kondisi percobaan yang dilakukan oleh kedua analis, sedangkan uji $\mathrm{F}$ dinyatakan dengan nilai $\mathrm{F}$ hitung kurang dari $\mathrm{F}$ tabel, hal ini menunjukkan bahwa tidak ada variasi yang berbeda nyata antara dua kondis percobaan yang dilakukan oleh kedua analis.

Tabel 7. Data Hasil Uji Presisi Antara

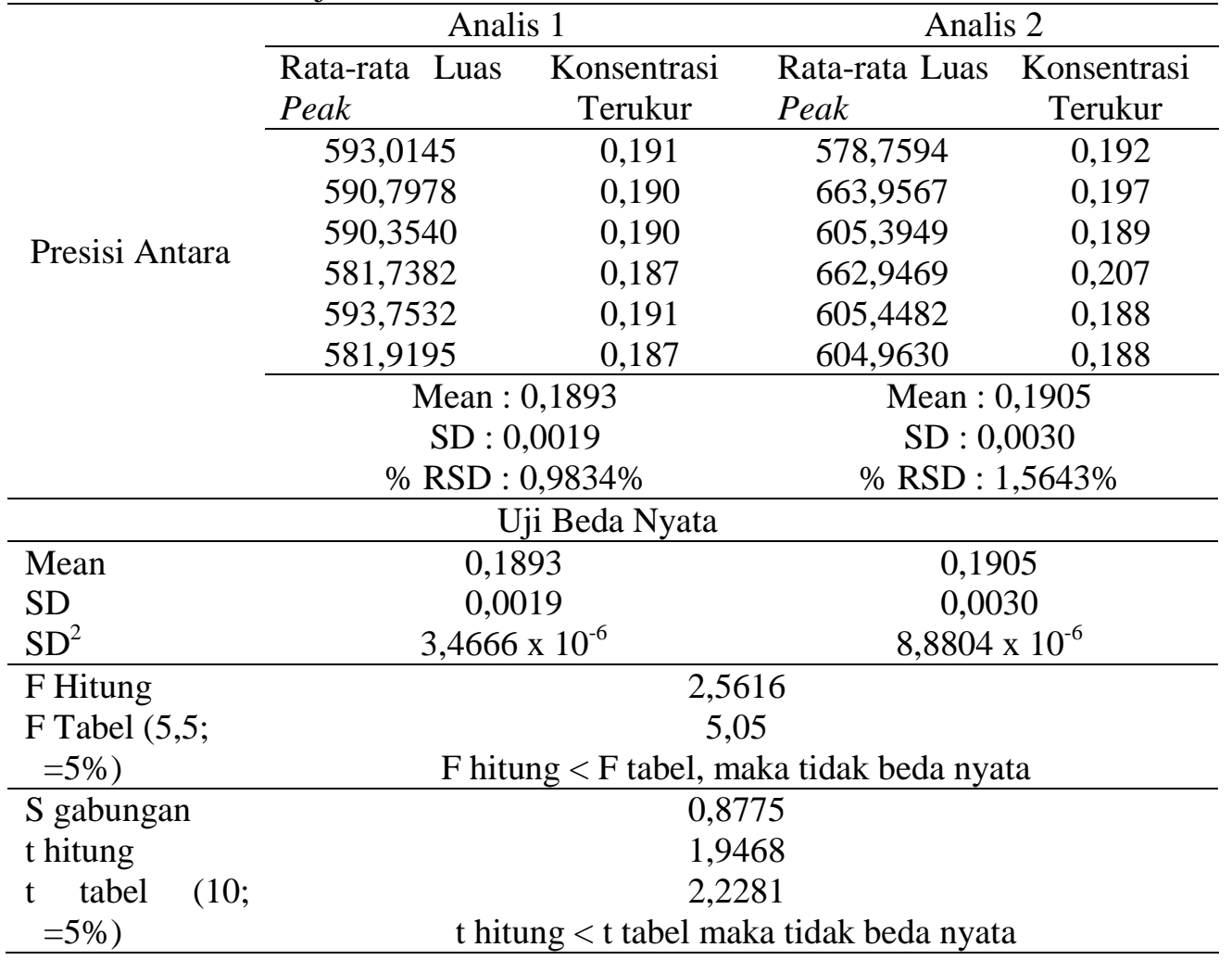


Hasil pengolahan data pada Tabel 7 diperoleh nilai $\mathrm{F}$ hitung $<\mathrm{F}$ tabel dan $\mathrm{t}$ hitung < t tabel, hal ini menunjukkan bahwa metode analisis ini tidak memberikan hasil yang bervariasi (berbeda nyata) jika dilakukan oleh analis yang berbeda pada waktu yang berbeda (memenuhi persyaratan).

\section{Akurasi}

Akurasi didefinisikan sebagai kedekatan antara nilai nyata yang dapat diterima sebagai nilai benar dengan nilai hasil pengukuran dari komponen yang sama. Akurasi dinyatakan sebagai persen perolehan kembali (\% recovery) yaitu hasil bagi nilai yang terukur dengan nilai teoritis dikalikan $100 \%$, dengan cara menetapkan kadar sejumlah tertentu analit yang ditambahkan ke dalam sampel atau sebagai selisih antara hasil rata-rata dengan hasil teoritis yang dapat diterima.

Akurasi dilakukan dengan cara menambahkan zat aktif ke dalam plasebo, baik zat aktif maupun plasebo, jumlahnya harus diketahui. Pengujian dilakukan dalam rentang validasi dari konsentrasi zat aktif dalam sampel. Pengujian ini rentang validasinya adalah 75\%-125\% konsentrasi zat aktif. Masing-masing konsentrasi dilakukan replikasi sebanyak enam kali. Kriteria penerimaan akurasi dinyatakan dalam rentang \% recovery.

Tabel 8. Kriteria Penerimaan Akurasi

\begin{tabular}{cc}
\hline $\begin{array}{c}\text { Konsentrasi Analit } \\
(\% \mathrm{~b} / \mathrm{v})\end{array}$ & $\%$ Recovery \\
\hline$>10 \%$ & $98-102 \%$ \\
$1,0-10,0 \%$ & $90-110 \%$ \\
$0,1-1,0 \%$ & $80-120 \%$ \\
$<0,1 \%$ & $75-125 \%$ \\
\hline
\end{tabular}

Hasil pengolahan data Tabel 9 diperoleh nilai \% recovery $108,98 \%$. Nilai ini telah memenuhi persyaratan yaitu $80-120 \%$. Hal ini menunjukkan bahwa metode analisis akurat.

Tabel 9. Data Hasil Uji Akurasi

\begin{tabular}{|c|c|c|c|c|c|}
\hline Konsentrasi & Luas Peak & $\begin{array}{l}\text { Rata-rata } \\
\text { Luas Peak }\end{array}$ & $\begin{array}{l}\text { Konsentrasi } \\
\text { Terukur }\end{array}$ & $\begin{array}{l}\% \\
\text { Recovery }\end{array}$ & $\begin{array}{l}\text { Rata-rata } \\
\% \\
\text { Recovery }\end{array}$ \\
\hline $0,175 \% \mathrm{~b} / \mathrm{b}$ & $\begin{array}{l}596,1243 \\
601,4328 \\
603,5101 \\
610,9238 \\
611,5111 \\
611,1744 \\
622,0206 \\
622,1307 \\
622,0809 \\
607,8072 \\
607,9291 \\
608,0864 \\
606,8330 \\
612,2286 \\
613,5933 \\
597,4036 \\
597,2740 \\
596,6804\end{array}$ & $\begin{array}{l}611,2031 \\
622,0773\end{array}$ & $\begin{array}{r}0,193 \\
0,191\end{array}$ & $\begin{array}{l}111,88 \\
111,28\end{array}$ & 108,98 \\
\hline
\end{tabular}




\section{KESIMPULAN DAN SARAN}

Hasil kinerja metode analisis diperoleh uji selektivitas berupa peak yang mampu memisahkan analit (PCMX) dalam sampel tanpa ada gangguan dari komponen lain dalam sampel. Uji linieritas menghasilkan nilai $\mathrm{r}>0,9996$. Presisi instrumen menghasilkan \% RSD untuk konsentrasi larutan standar $0,028 \mathrm{mg} / \mathrm{mL}$ dan $0,036 \mathrm{mg} / \mathrm{mL}$ berturut-turut adalah $0,08 \%$ dan $0,45 \%$. Keterulangan menghasilkan \% RSD sebesar 0,98\%. Presisi antara menunjukkan bahwa metode analisis tidak memberikan hasil yang bervariasi (berbeda nyata) jika dilakukan oleh analis yang berbeda pada waktu yang berbeda dan uji akurasi menghasilkan \% recovery sebesar $108,98 \%$.

Semua parameter uji memberikan hasil yang memenuhi kriteria penerimaan, sehingga metode analisis kadar PCMX (p-chloro m-xylenol) dalam sabun cair antiseptik menggunakan kromatografi cair kinerja tinggi dapat dipercaya dan dapat di-gunakan untuk analisis rutin di laboratorium Quality Assurance PT Reckitt Benckiser Indonesia. Kinerja metode analisis sebaiknya dilakukan secara berkala (setiap tahun) untuk menjamin validitas metode analisis yang digunakan.

\section{DAFTAR PUSTAKA}

Australian pesticides and Veterinary Medicines Authority.2003. Draft Guideline for The Validation of Analytical Methods. Australian pesticides and Veterinary Medicines Authority.

Badan Pengawas Obat dan Makanan. 2003. Pedoman Cara Pembuatan Kosmetika yang Baik. Jakarta: BPOM.

Badan Pengawas Obat dan Makanan. 2006. Pedoman Cara Pembuatan Obat yang Baik. Jakarta: BPOM.
Day, R.A. dan Underwood A.L. 1998. Analisis Kimia Kuantitatif. Edisi VI. Jakarta: Erlangga.

Fessenden, Ralp J., dan Joan S. Fessenden. 1982. Kimia Organik. Jilid II. Edisi III. Aloysius Hadyana Pudjaatmaka, penerjemah. Jakarta: Penerbit Erlangga.

Gritter, R.J., M. Bobbitt dan A.E. Schwarting. 1991. Pengantar Kromatografi. Edisi II. Kosasih Padmawinata, penerjemah. Bandung: Penerbit ITB. Terjemahan dari: Introduction to Chromatography.

Johnson, E.L. dan R. Stevenson. 1991. Dasar Kromatografi Cair. Kosasih Padmawinata, penerjemah. Bandung: Penerbit ITB. Terjemahan dari: Basic Liquid Chromatography.

Lindsay, Sandie. 1992. High Performance Liquid Chromatography. Second Edition. New York: John Willey and Sons.

Material Safety Data Sheet. 2007. pchloro m-xylenol. Dafeng Huaxin Bio-Tech Co., Ltd

Miller, J. C. and Miller, J. N. 1991. Statistika untuk Kimia Analitik. Edisi Kedua. Diterjemahkan oleh Suroso. Bandung: Penerbit ITB.

Mulja, H. M. dan Suharman. 1995. Analisis Instrumental. Surabaya: Airlangga University Press.

http://www.waters.com. High Performance Liquid Chromatography. Diunduh pada tanggal 4 Desember 2009. Pukul 17.45 WIB
http://www.waters.com. Coloumn Chromatography Catalogue. Diunduh pada tanggal 4 Desember 2009. Pukul 17.50 WIB

